\title{
Traditional Technology on Medicinal Plants Used by Indigenous People of Nongkhyllem Wildlife Sanctuary, Meghalaya, North East India
}

\author{
Shafiqul I. Bhuyan*, Imrana Laskar \\ Department of Botany, Pandit Deendayal Upadhyaya Adarsha Mahavidalaya, India \\ *Corresponding Author: safibhuyan@gmail.com
}

Received March 13, 2020; Revised April 13, 2020; Accepted April 27, 2020

Copyright $\bigcirc 2020$ by authors, all rights reserved. Authors agree that this article remains permanently open access under the terms of the Creative Commons Attribution License 4.0 International License

\begin{abstract}
Meghalaya a state in North Eastern Region of India is a rich source of biodiversity which includes high potential of naturally occurring medicinal plants. The study was conducted in and around the Nongkhyllem Wildlife Sanctuary located in the Ri-Bhoi district of Meghalaya to investigate the uses of medicinal plants and their conservation. The Nongkhyllem wildlife sanctuary was carved out of Nongkhyllem reserve forest in the year 1981 for adequate protection of the floral and faunal species of the area and covers an area of $29 \mathrm{sq}$. $\mathrm{km}$ on steep hill slopes $\left(20^{\circ}\right.$ to $\left.>65^{\circ}\right)$. Participation rural appraisal (PRA) methods and tools were used for interacting with them. Information was extracted through key informant interviews and focus group discussions. Plants specimen were collected and identified and preserved as voucher specimens following standard herbarium techniques. The study comprises 71 species of ethnomedicinal plants belonging to 42 families. The most dominant family recorded as a whole is Malvaceae followed by Euphorbiaceae, Fabaceae, Lamiaceae, Rutaceae, Solanaceae. Herbs were found to be the most used plants in preparing traditional medicines. Among the different plant parts, the leaves were most frequently used for the treatment of diseases followed by fruit, root, flower, bark, whole plant, seed, stem, rhizome and tuber. People collect plants from their surrounding plant communities in wild, semi-wild and some are cultivated as well. However, cultivation of medicinal plants in surroundings, home-gardens, agro-forestry systems is a very new and important from conservation point of view in north east India.
\end{abstract}

Keywords Biodiversity Conservation, Extinction, Climate Change, Deforestation, Sustainable Development

\section{Introduction}

The use of various parts of plants as indigenous medicine, food, shelter has been in vogue from ancient times. The ethno-botanical approach is very much important to involve the local people in conservation activities to conserve biodiversity and the environment. Moreover, a healthiest ecosystem with all the available factors on the earth can be controlled by the local communities, and they manage, protect and generate knowledge for which science may not have much information. However, many factors create remarkable stress on the local flora and fauna and cause the environmental degradation. These factors are forest disturbance, over exploitation, over human population, urbanization, agricultural extension, over grazing, deforestation etc. even traditional knowledge of plants utilization and their products are in danger of disappearing forever due above mention threats. However, a strong vice-versa interrelationship between plants and humans is found. Human activities are main responsible factor on plant communities with which they interact, the humans themselves are also influenced by plants. Especially medicinal plants have been using since prehistoric period in traditional healing systems for various diseases. Human knowledge of the medicinal value of plants date back perhaps for more than five thousand years [9]. Different medicinal plants and their uses are greatly well-known to indigenous communities of different parts of the world. They are expert for mounting inventive practices and products from their surroundings [10].

Meghalaya a state in North Eastern Region of India is a rich source of biodiversity which includes high potential of naturally occurring medicinal plants. The state has high concentration of plant species and harbours about 3128 (21\%) including 1237 endemic flowering plants in just $0.7 \%$ of the country's land area [5]. The state is predominantly hilly with varying climatic and forest vegetation zones which favors the growth of various medicinal plants. Among them a large number of plants have been well thought-out as important therapeutic aid for 
alleviate ailments of human kind. Meghalaya is divided into 3 hilly regions - Garo hills (Western Meghalaya), Khasi hills (Central Meghalaya) and Jaintia Hills (Eastern Meghalaya). Meghalaya has an estimated population of about 2,357,510 with a density of 104 people per sq. $\mathrm{km}$. Almost $70 \%$ of the total area of the state is covered by forest and $90 \%$ of this forest is covered by tribal communities [4].

Exploration on ethnomedicine used by different tribes of Meghalaya was done by many authors [2],[6],[7],[8]. However, a very few studies have been conducted among different tribal populations in addition to different types of protected areas of Meghalaya. Therefore, present study was undertaken to document different plant varieties used by different local people resided in around the Nongkhyllem Wildlife Sanctuary, Meghalaya.

\section{Materials and Methods}

\subsection{Study Site}

The study was conducted in and around the Nongkhyllem Wildlife Sanctuary located in the Ri-Bhoi district of Meghalaya. The sanctuary lies between $25^{\circ} 45^{\prime}$ $26^{\circ} 00^{\prime} \mathrm{N}$ latitude and $91^{\circ} 45^{\prime} 92^{\circ} 00^{\prime} \mathrm{E}$ longitude. The Nongkhyllem wildlife sanctuary and Nongkhyllem reserve forest are continuous. The Nongkhyllem reserve forest was constituted in the year 1910 with $96.91 \mathrm{~km}$ area. The Nongkhyllem wildlife sanctuary was carved out of Nongkhyllem reserve forest in the year 1981 for adequate protection of the floral and faunal species of the area and covers an area of 29 sq. $\mathrm{km}$ on steep hill slopes $\left(20^{\circ}\right.$ to $>$ $65^{\circ}$ ). The Umtrew River is the major river in the study area and it marks the western boundary of the Sanctuary and the Reserve Forest. Umran River forms the dividing boundary between the sanctuary and the reserve forest in the east and joins river Umtrew through the northern half of the sanctuary.

\subsection{Data Collection and Sampling Techniques}

Extensive fieldwork was carried out in the selected areas. Total four visits during four seasons were made to the study area. Knowledgeable consent was acquired from all village head prior to interviews. They were explained the reasons for conducting the survey and the information that will be collected. By direct contacts with the villagers' information was collected from all the study sites. Participation rural appraisal (PRA) methods and tools were used for interacting with them. Information was extracted through key informant interviews and focus group discussions. To find out the resources used by the local people of the area, sufficient numbers of people from different communities were interviewed. Representative from a minimum of twenty five percent of the total households were selection for interaction. In some villages up to forty percent were interacted. People of different ages, both male and female, traditional local doctors, plants collectors were interacted. A semi-structured questionnaire was used for the interviews. Information on plant use, plant parts used, processing, dosages, purpose of use, formulations, and side-effects, if any and storage were collected with the help of proper questionnaires. The collected information was evaluated for different genera and species of the medicinal plants in order to understand the pattern in medicinal plant uses and occurrences. With the help of information, field visits and collection of ethno-medicinal plants were done in all seasons. Plants were collected for herbarium records. Identification of collected plants species were done using vernacular names, published literatures and floras. Plants specimen were collected and identified and preserved as voucher specimens following standard herbarium techniques [3]. Herbarium was preserved in the department of Botany, PDUAM-Behali.

\section{Results and Discussion}

Ethno-botanical survey on traditional practices of medicinal plants was carried out in and around the Nongkhyllem Wildlife Sanctuary, Meghalaya. Local people reside near to the sanctuary have provided vast information regarding medicines and traditional health care practiced by them. Details result of the survey is presented in Table 1, the list of medicinal plants recorded from the tribal communities. The scientific name of the plants are arranged in alphabetical order, followed by its local name, family, habit, parts used, mode of use and disease classification. The study comprises 71 species of ethnomedicinal plants belonging to 42 families. The most dominant family recorded as a whole is Malvaceae (5 species); followed by Euphorbiaceae, Fabaceae, Lamiaceae, Rutaceae, Solanaceae (4 species), Begoniaceae, Asteraceae, Begoniaceae, Zingiberaceae (3 species), Anacardiaceae, Araceae, Papaveraceae, Plantaginaceae, Urticaceae (2 species), Amaranthaceae, Apiaceae, Apocynaceae, Araliaceae, Arecaceae, Asparagaceae, Betulaceae, Burseraceae, Caricaceae, Cephalolaxaceae (1 species) etc. (figure 4). Traditional healers belong to local communities are using the medicinal plant species to cure different disease such as Stomach problem, Diarrhoea, Rheumatism, Constipation, Wounds and cuts, Blood Pressure, Diabetes, Fever, Skin problems (skin, eczema, leprosy, ring worm, scabies, abscess, boils, burns, cut, wounds), Indigestion, Food poisoning, Toothache, Poison bites (dog bite, scorpion bite, snake-bite), Pneumonia, Jaundice, Cholera, Cough \& cold etc. (figure 1 \& 3). Herbs were found to be the most used plants in preparing traditional medicines i.e. 30 plant species, followed by shrub (22 species), tree (19 species), and climber (figure 2). Different plant parts were used as traditional medicine by the local people. 


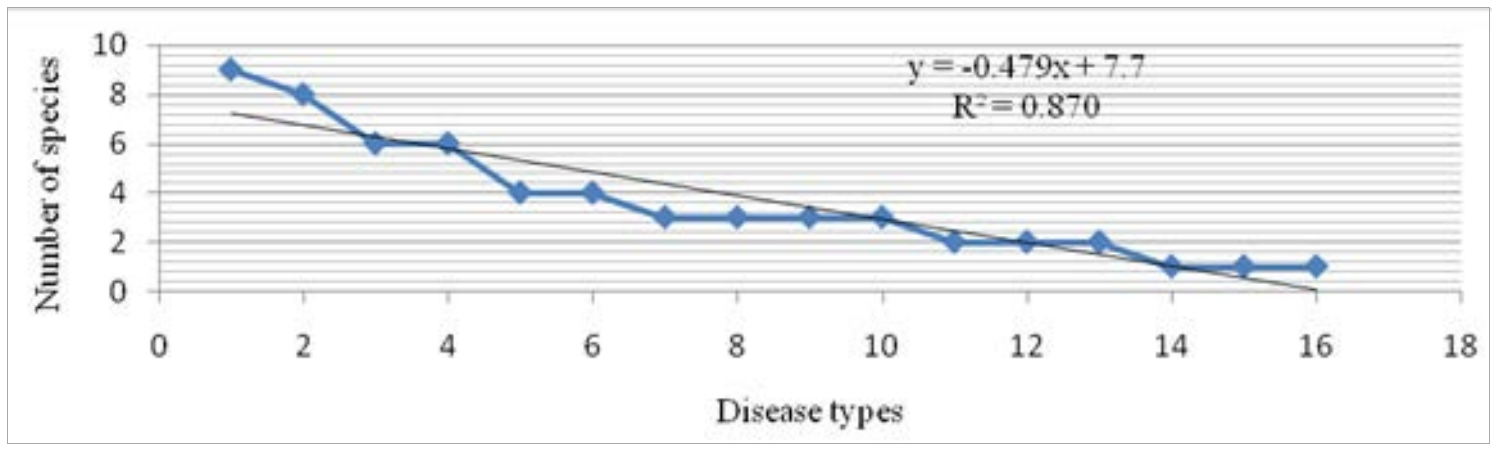

Figure 1. Number of plants used in different diseases

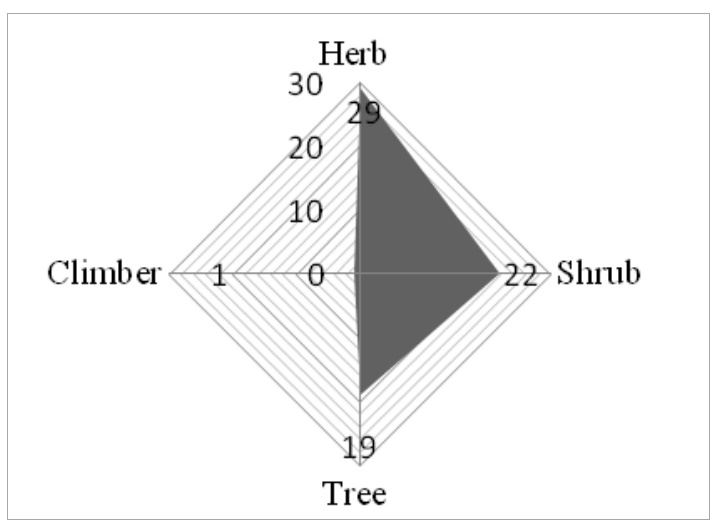

Figure 2. Habits of the plants used in medicines

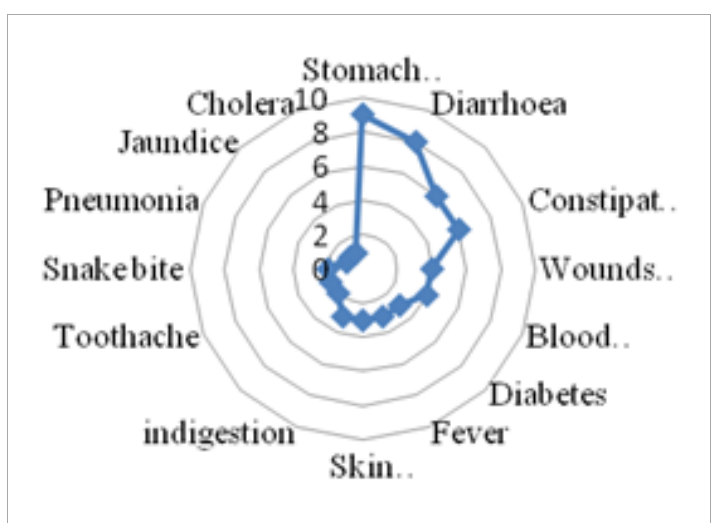

Figure 3. Diseases cured by plants

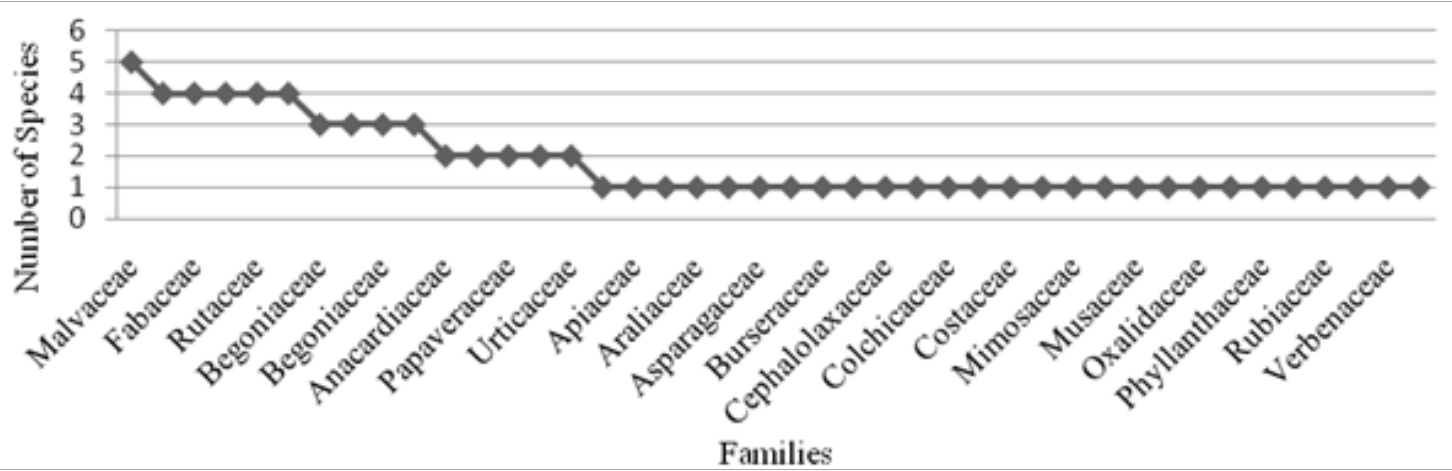

Figure 4. Number of plant species per family 
Table 1. List of Medicinal Plants used by local people of NWLS Meghalaya

\begin{tabular}{|c|c|c|c|c|c|c|}
\hline Sl No. & Botanical Name & Family & Habit & Parts Used & Mode of Use & Disease Classification \\
\hline 1 & Achyranthes asprera Linn. & Amaranthaceae & Herb & entire plant & Plant is boiled, water extract is used as a drink & $\begin{array}{c}\text { Pneumonia, Blood pressure, } \\
\text { diabetes }\end{array}$ \\
\hline 2. & Agave americana, Linn & Asparagaceae & Shrub & Leaf & Water extract and boiled leaves is drunk once a day. & T.B, Jaundice. \\
\hline 3 & Albizia chinensis (Osbeck.) Merr. & Fabaceae & Tree & Bark & Bark paste applied as antidote. & Insects, snake bite \\
\hline 4 & Alcea rosea Linn. & Malvaceae & Shrub & Flower & Mild purgative of the flower is consumed. & Stomach ache and gastric problem \\
\hline 5 & Alnus nepalensis D.Don. & Betulaceae & Tree & Root & Juice extract of root is drunk. & Diarrhoea \\
\hline 6 & Aloe vera (L.) Burm.f. & Xanthorrhoeaceae & Shrub & Leaf & Fleshy leaves paste applied on skin. & Wounds, cuts \\
\hline 7 & Antirrhinum majus Linn. & Scrophulariceae & Herb & Leaf & Leaves paste applied as poultice. & Tumours and ulcers \\
\hline 8 & Arctium lappa, Linn. & Asteraceae & Shrub & Leaf & Leaves are boiled and liquid extract is drunk. & Fever \\
\hline 9 & Argemone mexicana Linn. & Papaveraceae & Herb & Leaf & Leaves paste is applied on affected area & Wounds and ulcers \\
\hline 10 & Artemisia vulgaris, Linn. & Asteraceae & Herb & Leaf & Leaves paste is applied on skin & Rashes and ringworms \\
\hline 11 & Baccaurea ramniflora, Lour. & Phyllanthaceae & Tree & Seed & Paste of seed is consumed with water & Diarrhoea and dysentery. \\
\hline 12 & Begonia palmataD. Don. & Begoniaceae & Herb & entire plant & whole plant is crushed, liquid extracted is taken orally after food & Fever, stomach ache \\
\hline 13 & Begonia sp & Begoniaceae & Herb & Stem & Stem is eaten in raw form & Food poisoning \\
\hline 14 & Borassus aethiopum, Mart. & Arecaceae & Tree & Root & Water extract of boiled root is consumed & Indigestion, stomach problem \\
\hline 15 & $\begin{array}{l}\text { Butea buteiformis (Voigt) } \\
\text { Grierson, syn. }\end{array}$ & Fabaceae & Shrub & Seed & Pastes of seeds consumed with water & Parasitic worm infections \\
\hline 16 & $\begin{array}{c}\text { Butea } \\
\text { monosperma ,Roxb.ex.Willd. }\end{array}$ & Fabaceae & Tree & Bark & Bark is soaked in water, liquid is drunk & Piles, skin problems \\
\hline 17 & Cajanus cajan (Linn.) Mill. & Fabaceae & Shrub & Seed & Boiled seeds are consumed as anthelmintic. & Parasitic worm infections \\
\hline 18 & $\begin{array}{l}\text { Canarium resiniferum, } \\
\text { Bruce.ex.King. }\end{array}$ & Burseraceae & Tree & Fruit & Fruits are consumed & Indigestion \\
\hline 19 & Carica papaya, Linn. & Caricaceae & Tree & Fruit & Unripe fruit is consumed in raw form & Abortion \\
\hline 20 & Catharanthus roseus (L.) G.Don. & Apocynaceae & Herb & Leaf & Leaves are consumed in raw form. & Diarrhoea and dysentery \\
\hline 21 & Centella asiatica (L.) Urban. & Apiaceae & Herb & entire plant & Whole plant is taken in raw form. & Blood pressure and diabetes \\
\hline 22 & Cephalotaxus griffithii & Cephalolaxaceae & Shrub & Leaf & Leaves paste is consumed & Tumour \\
\hline 23 & Chenopodium album, Linn. & Chenopodiaceae & Herb & entire plant & Paste is consumed as laxative. & Constipation \\
\hline 24 & Citrus maxima, Burn. & Rutaceae & Tree & Fruit & Juice extract is drunk. & Indigestion \\
\hline 25 & Clerodendrum serratum, Linn. & Verbenaceae & Shrub & Stem & Juice extract is drunk. & Menstruation problem \\
\hline 26 & Colacasia sp & Araceae & Herb & Stem & Juice extract is used & Insect bite \\
\hline 27 & Colchicum autumnale, Linn. & Colchicaceae & Herb & Flower & Paste of the flower us used as massaging agent. & Rheumatism and Arthritis \\
\hline
\end{tabular}


Table 1 Continued

\begin{tabular}{|c|c|c|c|c|c|c|}
\hline 28 & Costus Speciosus, Sm. & Costaceae & Herb & entire plant & Paste is applied on the decayed tooth & Toothache \\
\hline 29 & Curcuma angustifolia Roxb. & Zingiberaceae & Herb & Rhizome & $\begin{array}{l}\text { Paste of rhizome is applied as massaging agent, paste is bound } \\
\text { with a cloth on fractures }\end{array}$ & Rheumatism and fractured bones \\
\hline 30 & Curcuma caesia Roxb. & Zingiberaceae & Herb & Rhizome & Rhizome paste is applied locally & Rheumatism and bruises \\
\hline 31 & Curcuma domestica, Val. & Zingiberaceae & Herb & Rhizome & Paste of the rhizome is applied on wounds for quick healing. & Wounds and cuts \\
\hline 32 & Datura innoxia, Mill. & Solanaceae & Shrub & Leaf, Flower & $\begin{array}{l}\text { Both Leaves and flower are crushed together, and used as } \\
\text { massaging agent. }\end{array}$ & Rheumatism \\
\hline 33 & Debregeasia longifolia Wedd. & Urticaceae & Tree & Fruit & Fruits are taken & Constipation \\
\hline 34 & Euphorbia antiquorum, Linn. & Euphorbiaceae & Tree & Bark & Liquid extract from boiled bark and drank & Constipation \\
\hline 35 & $\begin{array}{l}\text { Euphorbia pulcherrima, } \\
\text { Willd.ex.Klotzs. }\end{array}$ & Euphorbiaceae & Shrub & Stem & Milky latex of the stem applied & Skin rashes and ringworms \\
\hline 36 & Feronia limonia, Linn. & Rutaceae & Tree & Leaf & Leaves boiled, liquid extract is drank. & Fever \\
\hline 37 & Ficus Racemosa, Linn. & Moraceae & Tree & Fruit & Fruit is eaten. & Intestinal worms \\
\hline 38 & Helianthus annuus, Linn. & Asteraceae & Herb & Flower & Young flowers are crushed and applied as massage ointment. & Rheumatism \\
\hline 39 & Hibiscus mutabilis, Linn. & Malvaceae & Shrub & Leaf & Leaves chewed and consumed & Gastric pain \\
\hline 40 & Hibiscus rosa-sinensis, Linn. & Malvaceae & Shrub & Flower & Flower is crushed, consumed with water. & Menstruation problem \\
\hline 41 & Hibiscus sabdariffa Linn. & Malvaceae & Shrub & Fruit & Fruits are sliced, dried and consumed & Constipation \\
\hline 42 & Iris versicolor, Linn. & Iridaceae & Herb & Root & Dried roots are crushed and consumed & Liver infection \\
\hline 43 & Lasia spinosa, Thwaites. & Araceae & Herb & immature Shoot & shoots are boiled and consumed & Intestinal worms \\
\hline 44 & Leucas aspera, Spreng. & Lamiaceae & Herb & Leaf & Crushed leaves used for inhale & Sinus \\
\hline 45 & Litsea citrata, Blume. & Rutaceae & Tree & Leaf & Boiled leaves consumed. & Blood Pressure \\
\hline 46 & Manihot esculentaCrantz. & Euphorbiaceae & Shrub & Leaf & Decoctions of the leaves are applied locally & Skin disease \\
\hline 47 & Manihot sp. & Euphorbiaceae & Shrub & Tuber & Juice extract of tuber applied & Rashes and skin allergy. \\
\hline 48 & Mentha spicata Linn. & Lamiaceae & Herb & Leaf & Juice extract of leaves are consumed. & Diarrhoea and constipation. \\
\hline 49 & Mimosa pudica, Linn. & Mimosaceae & Herb & Leaf & Leaves paste is applied on cuts & Wounds and cuts \\
\hline 50 & Murraya koenigii, Linn. & Rutaceae & Tree & Leaf & Leaves paste is consumed with water and salt & Diarrhoea and dysentery \\
\hline 51 & Musa paradisiaca, Linn. & Musaceae & Herb & Fruit & Ripe fruit is taken & Constipation \\
\hline 52 & Mussaenda roxburghii, Hook.F. & Rubiaceae & Shrub & Root & Roots soaked in water for whole night, liquid extract is drunk. & Gastric pain \\
\hline 53 & Ocimum basilicum, Linn. & Lamiaceae & Herb & Leaf & Leaves chewed & Stomach pain \\
\hline 54 & Oxalis acetosella, Linn. & Oxalidaceae & Herb & Leaf & Consumption of boiled leaves & Kidney and urinary infection. \\
\hline 55 & Panax quinquefolius, Linn. & Araliaceae & Herb & Tuber & $\begin{array}{l}\text { Dried and crushed powder of the tuber is mixed with water and } \\
\text { drank regularly for a few days }\end{array}$ & Diabetes \\
\hline 56 & Papaver somniferum, Linn. & Papaveraceae & Herb & Seed & seed paste is consumed with water. & Stomach pain \\
\hline
\end{tabular}


Table 1 Continued

\begin{tabular}{|c|c|c|c|c|c|c|}
\hline 57 & Passiflora edulis, Sims. & Passifloraceae & Climber & Leaf & Decoction of boiled Leaves consumed. & Blood pressure \\
\hline 58 & Plantago asiatica, Linn. & Plantaginaceae & Herb & Seed & Seed paste is massaged on affected area & Fractures and sprains \\
\hline 59 & Plantago major, Linn. & Plantaginaceae & Herb & Leaf & Paste of leaves applied. & Wounds and cuts \\
\hline 60 & Psidum guajava, Linn. & Myrtaceae & Tree & Leaf & Leaves chewed and consumed & Diarrhoea and dysentery \\
\hline 61 & Rhus simialata, Murr. & Anacardiaceae & Tree & Fruit & fruit mixed in water and consume & Food poisoning \\
\hline 62 & Rubus ellipticus, Sm. & Rosaceae & Shrub & Root & Juice extract of the root is drunk. & Kidney problem \\
\hline 63 & Salvia officinalis, Linn. & Lamiaceae & Shrub & Flower & Flower paste is applied on skin & Snake and insect bite \\
\hline 64 & Solanum khasianum, Clarke. & Solanaceae & Shrub & Fruit & Ripe fruit smoked and inhaled orally. & Toothache \\
\hline 65 & Solanum kurzii, Brace ex prain. & Solanaceae & Shrub & Fruit & Decoction of the fruit is drunk & Hepatitis \\
\hline 66 & Solanum torvumSw. & Solanaceae & Shrub & Leaf & Pastes of leaves are applied & Cuts and wounds. \\
\hline 67 & Spondias mangifera, Willd. & Anacardiaceae & Tree & Fruit & Juice extract consume as drink & Diarrhoea and dysentery \\
\hline 68 & $\begin{array}{c}\text { Stereospermum chelonoides (H.F) } \\
\text { Dc. }\end{array}$ & Begoneaceae & Tree & Bark, root & Liquid extract of root and bark are consumed. & Cholera \\
\hline 69 & Terminalia chebula, Retz. & Combretaceae & Tree & Fruit & Fruit is boiled and liquid extract drank. & Diarrhoea and dysentery \\
\hline 70 & Urena lobata Linn. & Malvaceae & Shrub & Root and bark & Paste of root $\&$ bark is used as massage ointment. & Rheumatism \\
\hline 71 & Urtica dioica & Urticaceae & Herb & Leaf & Leaves are soaked in water and massaged onto body swellings. & Body sores and swellings. \\
\hline
\end{tabular}


Among the different plant parts, the leaves were most frequently used for the treatment of diseases followed by fruit, root, flower, bark, whole plant, seed, stem, rhizome and tuber (figure 3). The methods of preparation fall into different categories such as plant parts applied as a paste, decoction, juice extracted from the fresh plant parts, boiled root, powder made from fresh or dried plant parts. Medicines are mostly taken orally and by topical or local applications also observed. Both the external (mostly for snake bites, wounds and skin diseases) and internal consumption of the preparations were involved in the treatment of diseases.

All the medicinal plants are generally found in each of the villages in this region. Local people used to collect plants from their surrounding plant communities in wild, semi-wild and some are cultivated as well. It was found that most of the plant parts used as medicines to cure diseases gathered from forest, but some rural people are devoted to raise certain plants with medicinal properties [1]. However, cultivation of medicinal plants in surroundings, home-gardens, agro-forestry systems is a very new and important from conservation point of view in north east India.

It was found that medicinal plants played a very important role in the health care system of these tribal communities. It is seen that rural community's health care seems to be the first and foremost line of defense. In spite of the advancement of science and technology, modern civilization and other activities, most of them are still holding on their traditional practices of medicinal systems. Regional indigenous knowledge is mainly confined to the traditional-healers and old-folks residing in villages. However, traditional healers think that the knowledge of the medicinal effectiveness of plants is being missing as they do not divulge the secret in fear. Even they also in tension that their professional supremacy may be at risk and the uses of medicinal potency of the plants would be destabilized. However, proper documentation of medicinal plants is very essential to know their potential for the improvement of health and hygiene through an eco-friendly system. Therefore, extra importance on ethno medicinal research would be helpful and effective strategy for the discovery of useful medicinally active identity. However, recent study has revealed that many of these valuable plants is under threat and depleting very fast deforestation, overexploitation of plant resources, practice of 'Jhum' or 'Shifting' cultivation, forest fire and other human socio-economic developmental activities in the area. Therefore, it is urgent need for protection and conservation of biodiversity including the valuable assets of medicinal plants. Different types of strategies are required to adopt, involving all the local people called community-based conservation systems.

\section{Acknowledgements}

The authors are thankful to SERB-DST, Govt. of India for financial assistant (ECR/2017/000369 Dated: $29^{\text {th }}$ May, 2017). Authors are also thankful to the local community for their co-operation during field survey.

\section{REFERENCES}

[1] Bhuyan, S.I. and Baruah, B.N., Medicinal Plants Used for the Treatment of Respiratory Disorders: A Study in Bongaigaon, North Eastern Himalayan Sub-region of India. The Pharma Innovation Journal (TPI). Volume 4, Issue 2. 2015.

[2] Choudhuri, D. and Neog, B., Ethnobotany of Khasi and Chakama tribes of north east India. Ethnobotany and medicinal plants of Indian subcontinent, edited by JK Maheshwari (scientific publisher, new Delhi). P 583,2003.

[3] Jain, S.K. and Rao, R.R., A handbook of fields and herbarium methods. Today and Tomorrows Publishers, New Delhi; Pp 1077, 1977.

[4] Jaiswal, V. 2010. culture and ethnobotany of jaintia tribal community of Meghalaya, North-east India- A mini review. Indian journal of traditional knowledge. Vol-9(1). P 38-44

[5] Khan, M.L, Menon, S. and Bawa, K.S., Effectiveness of the protected area network in biodiversity conservation: a case study of Meghalaya state. Biodiversity conservation 6. P 853-868, 1997.

[6] Kharkongor, P. and Joseph, J., Folkrore medicobotany of rural Khasi and Jaintia tribes in Meghalaya. Glimpses of Indian ethnobotany, edited by SK Jain (oxford and IBH New Delhi). P 115, 1981.

[7] Laloo, R.C, Kharlukhi, L. Jeeva S. and Mishra B.P., Status of medicinal plants in the disturbed and the undisturbed sacred forests of Meghalaya, northeast India: population structure and regeneration efficacy of some important species. Current Science, VOL. 90, No. 2, P 225-232, 2006.

[8] Rao, R.R., Ethnobotanical studies on the flora of Meghalaya some interesting report on herbal medicine. Glimpses of Indian ethnobotany, edited by SK Jain (oxford and IBH New Delhi). P 137, 1981.

[9] Sofowora, A., Medicinal Plants and Traditional Medicinal in Africa. John Wiley and Sons, New York, P 256, 1982.

[10] Tiwari, J.K, Ballabha R. and Tiwari, P. Diversity and Present Status of Medicinal Plants in and around Srinagar Hydroelectric Power Project in Garhwal Himalaya, India: Needs for Conservation. Researcher; Vol-2(2). P 50-60, 2010. 